\title{
Increase in soil nutrients in intensively managed cash-crop agricultural ecosystems in the Guanting Reservoir catchment, Beijing, China
}

\author{
Xinyu Zhang ${ }^{\mathrm{a}, \mathrm{b}}$, Liding Chen ${ }^{\mathrm{b}, *}$, Qi Li ${ }^{\mathrm{b}}$, Xin Qi ${ }^{\mathrm{b}}$, Shuang Yang ${ }^{\mathrm{b}}$

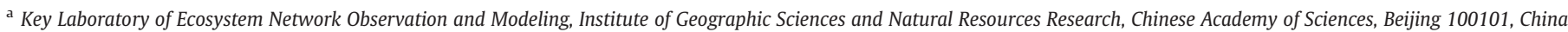 \\ b State Key Laboratory of Regional and Urban Ecology, Research Center for Eco-Environmental Sciences, Chinese Academy of Sciences, Beijing 100085, China
}

\section{A R T I C L E I N F O}

\section{Article history:}

Received 24 June 2011

Received in revised form 24 September 2012

Accepted 29 September 2012

Available online 17 November 2012

\section{Keywords:}

Agricultural land-use

Cash crop

Management practices

Soil nutrients

Fertilization

\begin{abstract}
A B S T R A C T
Since the late 1970s, transitions in socioeconomic status and new governmental policies have led to drastic changes in agricultural land use types and farm management practices across rural China, such as an increase in the area of land cultivated for cash-crops (e.g. vegetables and orchards) and intensive fertilization and irrigation of this land. How this more intensive management and land use for the more profitable cash crops affects soil nutrients is of great concern for carbon, soil and water quality management. In this paper, we attempted to assess the influence of cash crop ecosystems on soil nutrients in the catchment upstream of the Guanting Reservoir, in the Beijing municipality, North China plain. Soil nutrients in cash crop (orchard and vegetable) ecosystems with between 8 and 20 years of intensive management history were compared with traditional agro-ecosystem management patterns (corn and soybean). Results showed that soil organic carbon (SOC) had improved, and total nitrogen $(\mathrm{N})$, and available phosphorus $(\mathrm{P})$ concentrations had marginally increased under intensive management practices in the vegetable and orchard ecosystems in the last 25 years. The increases in SOC and total P densities at the $100 \mathrm{~cm}$ soil depth in orchard, vegetable and irrigated corn systems were greater than those in the rain fed corn and soybean systems. Soil available P and electrical conductivity (EC) were highest in the vegetable lands. However, no significant changes were found between the soil physical properties (i.e. bulk density, clay content and water stable aggregate content) of the traditional and cash-cropping systems. Multi regression analysis showed that manure and mineral fertilizer contributed significantly to the increase in soil nutrients. Intensively managed orchards are a better option for improving soil quality and SOC sequestration. However, the risks of nonpoint source pollution from, and soil salinization in, the land used for vegetable cultivation should be considered in the future.
\end{abstract}

(c) 2012 Elsevier B.V. All rights reserved.

\section{Introduction}

Agriculture in China has seen significant advances since the late 1970s, when the new land policy 'Household Responsibility System' was implemented. As a result, the combination of an evolving socioeconomic environment and new governmental policies has resulted in drastic changes in agricultural land-use and farm management in rural China (Chen et al., 2001, 2006; Fu et al., 2001; Zhang et al., 2004). Driven by economic profit, agricultural land-use has evolved from subsistence field cropping to the growing of cash crops (Qin et al., 2007). Between the 1980s and 2000s, use of mineral fertilizer and manure has doubled or quadrupled in the periphery of Beijing (Zhang et al., 2004). The effects of this intensive fertilization and cultivation of cash crops on soil nutrients, soil physical and environmental quality are of great concern, especially in water source catchments.

\footnotetext{
* Corresponding author at: State Key Laboratory of Regional and Urban Ecology, Research Center for Eco-Environmental Sciences, Chinese Academy of Sciences, P.O. Box 2871, Beijing 100085, China. Tel./fax: + 861062943840 .

E-mail addresses: liding@rcees.ac.cn, chenliding@sohu.com (L. Chen).
}

Soil nutrients, e.g. soil organic carbon (SOC), nitrogen (N) and phosphorus $(\mathrm{P})$, play a crucial role in sustaining soil quality, crop production and environmental quality (Bennett et al., 2005; Franzluebbers and Stuedemann, 2010; Hooda et al., 2001; Lal, 2004a, 2004b). Increasing SOC through higher mineral fertilizer and crop residue inputs is a valuable option for sustainable agriculture production in areas with low SOC (Xu et al., 2006). However, evidence shows that intensive vegetable farming has the potential to damage soil health, and can lead to poor productivity and considerable environmental pollution (Wells et al., 2000).

Before 1997, the Yanhuai basin was one of the important agricultural catchments of the Guanting reservoir, and had been used as a drinking water source for the Beijing municipality. Since 1997, however, it has only been used as an agricultural and industrial water source because of point and nonpoint source pollution from the catchment (Wang et al., 2007).

Mitigation options for reducing the potential of nonpoint source pollution from the agricultural areas in the catchment should be implemented urgently. However, to date, little is known about the effects of the intensively managed, yet more profitable, vegetable 
and orchard farming systems on soil organic carbon (SOC), nitrogen $(\mathrm{N})$, phosphorus $(\mathrm{P})$ and other soil properties in this catchment over the last two decades, which makes it difficult to implement effective soil and water management plans.

We believe that, in the orchard systems, increases in mineral and manure fertilization, and litter return may improve the SOC content, and may decrease the soil bulk density. However, the increased outputs will remove more soil $\mathrm{N}$ and $\mathrm{P}$ than the less intensive farming systems, and therefore will decrease the soil nutrient status.

In the vegetable systems, mineral and manure fertilizer applications may increase the SOC, $\mathrm{N}$ and $\mathrm{P}$ contents, but equally, the increased outputs and higher irrigation frequency may remove more soil $\mathrm{N}$ and $\mathrm{P}$ than has been applied in fertilizer. For the irrigated corn land, soil nutrients may have improved over the past 25 years due to the increased fertilizer inputs and residue return.

In this study, we compared soils cultivated for cash crops (orchard and vegetable), with a history of intensive management for between 8 and 20 years, with soils under traditional agro-ecosystem management (corn and soybean). Our objectives were: (1) to compare patterns in the variations of SOC, total N, total P and available P over the past 25 years; and (2) to examine how the cultivation of cash crops and the different agro-ecosystem management practices have affected soil nutrients. Results from this study will be helpful for managing carbon storage, and sustaining soil and water quality in similar water source catchments.

\section{Materials and methods}

\subsection{Study sites}

The study was conducted in the Yanhuai basin $\left(40^{\circ} 16^{\prime}-47^{\prime} \mathrm{N}\right.$, $115^{\circ} 44^{\prime}-116^{\circ} 34^{\prime} \mathrm{E}$ ), upstream of the Guanting Reservoir, in the northwestern region of Beijing (Fig. 1a). The Yanhuai basin covers about $450 \mathrm{~km}^{2}$, with elevation ranging from 480 to $580 \mathrm{~m}$. The climate is warm and sub-humid. The mean annual temperature is $8.5^{\circ} \mathrm{C}$, the frost-free period is 161 days, and the mean annual precipitation is $442 \mathrm{~mm}$ (Li et al., 2007). The dominant soils can be classified as Ustochrepts (Soil Survey Staff, 2010).

\subsection{The sampling sites and their management practices}

Soil samples were collected in 1980, during the second National Soil Survey of China, and again in 2005. In 2005, the sampling sites used in 1980 were relocated using the plot names given in the Yanqing Soil Reference Book (Yanqing Soil Survey Staff, 1983) and on the Yanqing County Soil Nutrient Map (1:25000). The locations were recorded by
GPS and resampled (Fig. 1a). In order to compare the effects of the more profitable vegetable-fruit ecosystems and traditional cropping systems on soil nutrients, and to select the long-term vegetable and orchard ecosystems for sampling, questionnaire surveys were conducted among the local farmers. Information on detailed management practices on the traditional cropping systems and more profitable vegetable and orchard systems was obtained through the questionnaires and field surveys.

Six vegetable and four orchard ecosystems, converted from traditional cropping systems over the past 8 to 20 years, were sampled. Three soybean and twenty-eight corn ecosystems were sampled uniformly in the Yanhuai basin (Fig. 1a). Corn accounts for the majority of the traditionally cropped land in the study area. This corn farmed land was further classified as either irrigated or rain fed. The soybean areas were all rain fed.

\subsection{Soil sampling and analysis}

In 1980 soil samples were collected and analyzed by the second Chinese National Soil Survey staff of Yanqing County, in accordance with the Technical Regulations of the Second National Soil Survey of China (Yanqing Soil Survey Staff, 1983).

For each sampling site in 2005, 5 samples were collected in the spring before tillage and seeding along a $100 \mathrm{~m}$ transect and combined into one composite sample for soil nutrient analysis. Soil samples of $10 \mathrm{~cm}^{3}$ each were collected from a depth of 0-20 cm using a spade for soil water-stable aggregate assessment. Samples were collected for soil bulk density assessment with a $100 \mathrm{~cm}$ deep soil auger and sectioned into $0-10 \mathrm{~cm}, 10-25 \mathrm{~cm}, 25-50 \mathrm{~cm}, 50-70 \mathrm{~cm}$ and $70-100 \mathrm{~cm}$ increments.

Soil water-stable aggregate greater than $0.25 \mathrm{~mm}$ (AGG) was measured using a wet sieving method (Elliott, 1986). Soil bulk density $\left(D_{b}\right)$ in the field was estimated by the core method, using the oven-dried soil mass and the field volume of the sample (Blake and Hartge, 1986).

After roots and visible plant residues were removed from soil samples, soil was passed through a $1 \mathrm{~mm}$ sieve and kept in a refrigerator for determination of microbial biomass carbon (MBC), $\mathrm{pH}$ and EC. The remaining fresh portion of the soil samples was air-dried and analyzed for soil particle size and available P. A portion of the air-dried soil samples was ground further, and passed through a $0.16 \mathrm{~mm}$ sieve for SOC, total $\mathrm{N}$ and total $\mathrm{P}$ analyses.

Soil particle size was measured using a Laser Particle Size Analyser (Master Sizer 2000, Malvern, UK) (Physical Geography Laboratory Manual, 2003). SOC was determined via rapid dichromate oxidation of dried ground samples (Tiessen and Moir, 1993) and total N by a

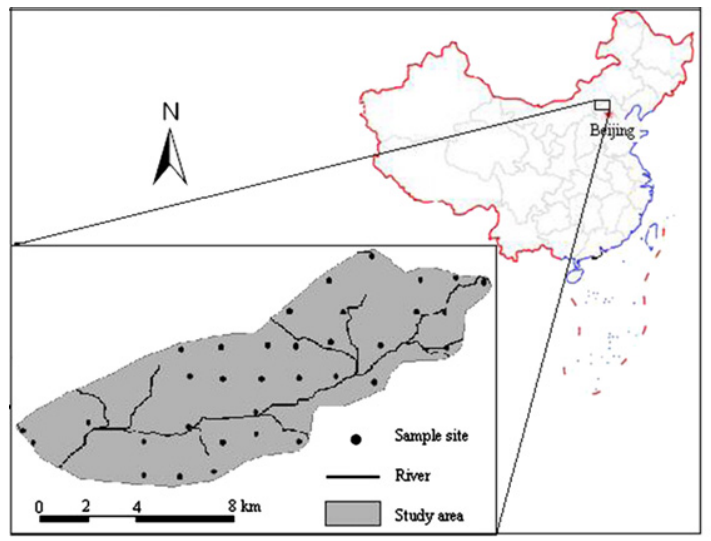

b

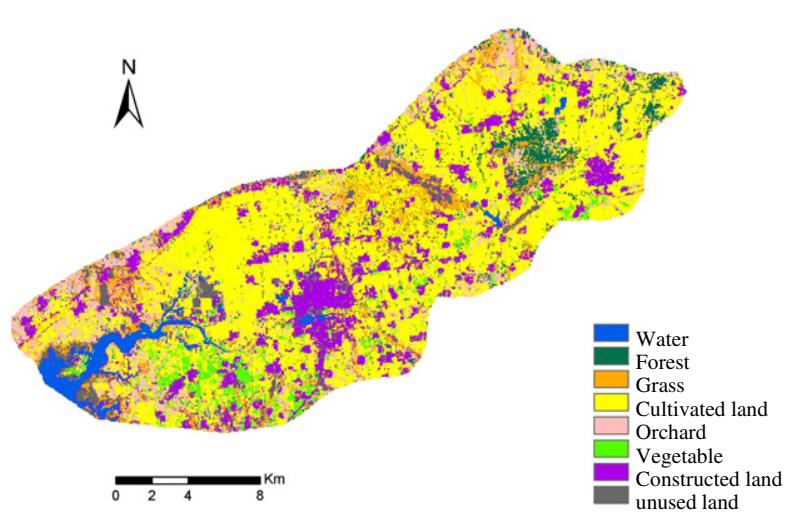

Fig 1. The study area in China and distribution of soil sampling sites (a) and land-use of the research sites (b). 
the Kjeldahl method (McGill and Figueiredo, 1993). Total P was determined after digestion with concentrated sulfuric acid and perchloric acid, using the molybdate-ascorbic acid method (Olsen and Sommers, 1982); and available P was determined using the bicarbonate extraction method of Olsen and Sommers (1982). Fresh soil pH and EC (soil:water, $1: 2.5$ ) were measured using a $\mathrm{pH}$ and EC meter. Fresh soil microbial biomass carbon (MBC) was determined by the chloroform fumigation$\mathrm{K}_{2} \mathrm{SO}_{4}$ extraction method (Jenkinson and Powlson, 1976), and the $\mathrm{C}$ in the extract was analyzed by a total carbon analyzer (Liqui TOCII, elementar, Germany).

\subsection{Calculation}

The soil nutrient densities were calculated as follows:

$$
\text { Soil nutrient densities }(\mathrm{C}, \mathrm{N}, \text { and } \mathrm{P}) \begin{array}{r}
\left(\mathrm{kg} \mathrm{m}^{-2}\right) \\
=\text { Soil nutrient content }\left(\mathrm{g} \mathrm{kg}^{-1}\right) \\
\times \mathrm{D}_{\mathrm{b}}\left(\mathrm{g} \mathrm{cm}^{-3}\right) \times \text { Soil depth }(\mathrm{m}) .
\end{array}
$$

We used $D_{b}$ measured from field sampling for the top $25 \mathrm{~cm}$ of the soil profile in the calculations. For the $25 \mathrm{~cm}$ to $100 \mathrm{~cm}$ increments, we computed the bulk density values $\mathrm{D}_{\mathrm{b}}\left(\mathrm{mg} \mathrm{m}^{-3}\right)$ according to Rawls formula (1983) as follows:

$\mathrm{D}_{\mathrm{b}}=\frac{100}{\frac{\mathrm{OM}}{\mathrm{VOM}}+\frac{100-\mathrm{OM}}{\mathrm{VMF}}}$

where $\mathrm{OM}=\%$ soil organic matter $(\mathrm{OM})$ content (calculated by multiplying the SOC content by a factor of 1.724), and VOM = bulk density of the organic fraction $=0.224 \mathrm{mg} \mathrm{m}^{-3}$. The VMF per texture class was taken from the Texture Triangle (Lettens et al., 2005), and the international classification standard was used for texture classification.

The MBC values were computed as follows (Jenkinson and Powlson, 1976):

$\mathrm{MBC}=\mathrm{E}_{\mathrm{C}} / 0.38$

where $\mathrm{E}_{\mathrm{C}}$ is the difference in organic $\mathrm{C}$ concentration between the fumigated and unfumigated soils, and 0.38 is the extractable part of microbial biomass $\mathrm{C}$.

\subsection{Statistics}

One-way ANOVA was used to test for significant differences in soil properties and nutrient densities between land use types. The significance level used was $p<0.05$. A paired t-test was used to test for significant differences between 1980 and 2005. The relationships between soil nutrients, and manure and mineral fertilization were determined by stepwise regression. The independent variables used in this study were land use systems. These were divided into five classes, orchard, vegetable, irrigated corn, rain fed corn and rain fed soybean. Each class was given a numeric value from 1 to 5 . Data were analyzed with SPSS 11.0 (Chicago, IL, USA).

\section{Results}

\subsection{Agricultural land-use and management change}

The research area has been traditionally cultivated, and has a long history of corn and soybean cultivation. About $90 \%$ of the land in this area is used for agriculture, which is made up of traditionally cultivated lands (comprising corn and soybean cropping systems), and the more profitable vegetable and orchard systems (Fig. 1b). Since the Chinese Rural Reform, this area has experienced rapid expansion in the extent of land cultivated for vegetables and orchards. Between 1982 and 2003 , land used for orchards increased from $21.51 \mathrm{~km}^{2}$ to $46.33 \mathrm{~km}^{2}$, while the area under vegetable cultivation increased from $11.76 \mathrm{~km}^{2}$ to $49.52 \mathrm{~km}^{2}$, (Yanqing County Official Statistical Agency, 1982, 2004).

Driven by economic profits, farmers have adopted more intensive fertilization and irrigation practices on the most suitable land. The average net incomes from vegetable cultivation and orchards were 10-23 and 15-30 thousand yuan (RMB) $\mathrm{ha}^{-1}$ year $^{-1}$, respectively, compared with 6-7.5 thousand yuan (RMB) $\mathrm{ha}^{-1}$ year $^{-1}$ from the irrigated corn land, and approximately 3-5 thousand yuan (RMB) ha ${ }^{-1}$ year $^{-1}$ from the areas under rain fed corn and soybean.

The irrigation regime was as follows: ridge irrigation 1-2 times each year for the irrigated corn areas, flood irrigation between 4 and 6 times annually for the orchard lands, and bed irrigation 20 times annually for the areas under vegetable cultivation. Manure was not added to either the rain fed corn or soybean lands. The average amount of organic manure (cattle or chicken compost) applied to the orchard, vegetable and irrigated corn lands was about 900, 1790 and $450 \mathrm{~kg} \mathrm{OM} \mathrm{ha}{ }^{-1}$ year $^{-1}$, respectively, total $\mathrm{N}$ inputs were about 740,917 and $305 \mathrm{~kg} \mathrm{Nha}^{-1}$ year $^{-1}$, respectively, and total P inputs amounted to 103,153 and $86 \mathrm{~kg} \mathrm{Pha}^{-1}$ year $^{-1}$, respectively (Fig. 2). Inputs of total $\mathrm{N}$ to rain fed corn and soybean lands were 200 and $50 \mathrm{~kg} \mathrm{Nha}^{-1}$ year $^{-1}$, respectively, while the inputs of total $\mathrm{P}$ were 66 , and $16 \mathrm{~kg} \mathrm{Pha}^{-1}$ year $^{-1}$, respectively (Fig. 2).

\subsection{Comparison of soil nutrients in 1980 and 2005}

Results showed that SOC, total $\mathrm{N}$ and available P concentrations increased from 1980 to 2005 (Fig. 3.). In 1980, concentrations of SOC, total $\mathrm{N}$ and available P were low, without any obvious difference between sampling sites, and ranged from 5.10 to $6.84 \mathrm{~g} \mathrm{~kg}^{-1}$, from 0.63 to $0.80 \mathrm{~g} \mathrm{~kg}^{-1}$ and from 3.8 to $8.5 \mathrm{mg} \mathrm{kg}^{-1}$, respectively. In 2005, SOC and total $\mathrm{N}$ ranged from 7.87 to $10.00 \mathrm{~g} \mathrm{~kg}^{-1}$ and from 0.75 to $1.12 \mathrm{~g} \mathrm{~kg}^{-1}$, respectively, while available P ranged from 17.4 to $66.1 \mathrm{mg} \mathrm{kg}^{-1}$ in the sampling sites (Fig. 3.).

From 1980 to 2005, SOC increased significantly $(p<0.01)$ in the orchard ( $96 \%$ increase), vegetable ( $42 \%$ increase) and irrigated corn (37\% increase) soils. Total $N$ increased significantly $(p<0.05)$ in the orchard (70\% increase) and vegetable (51\% increase) cultivated soils. Available P increased significantly $(p<0.05)$ in all land uses, so that by 2005, available P was 1.8 times higher in the soybean soils, and 6.8 times higher in the vegetable soils, than in 1980 (Fig. 3.).

\subsection{Effects of agricultural land-use on soil nutrient densities}

When expressed on an area basis to a profile depth of $100 \mathrm{~cm}$ (except available P), soil nutrient densities are influenced by two factors: nutrient

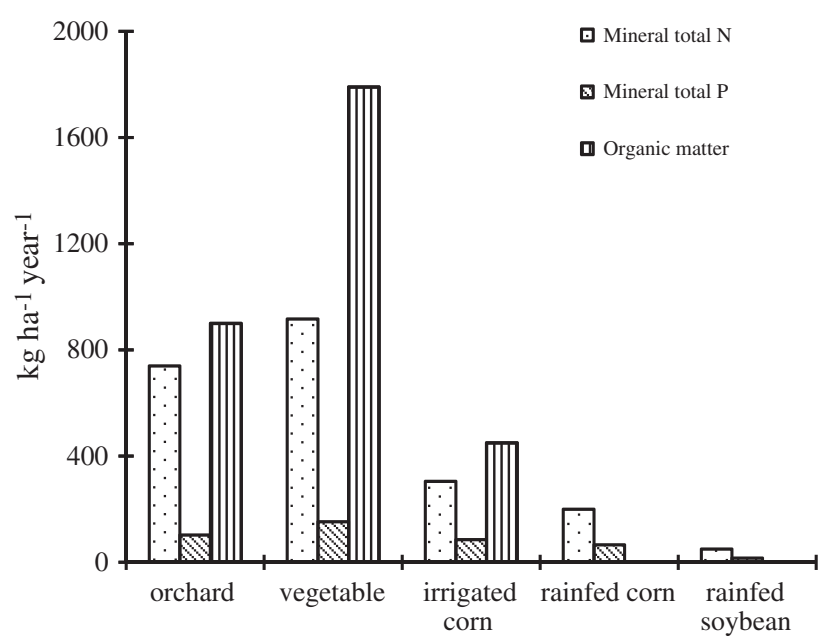

Fig. 2. Manure and mineral fertilizer use in the agro-ecosystems from households surveyed in 2005. 

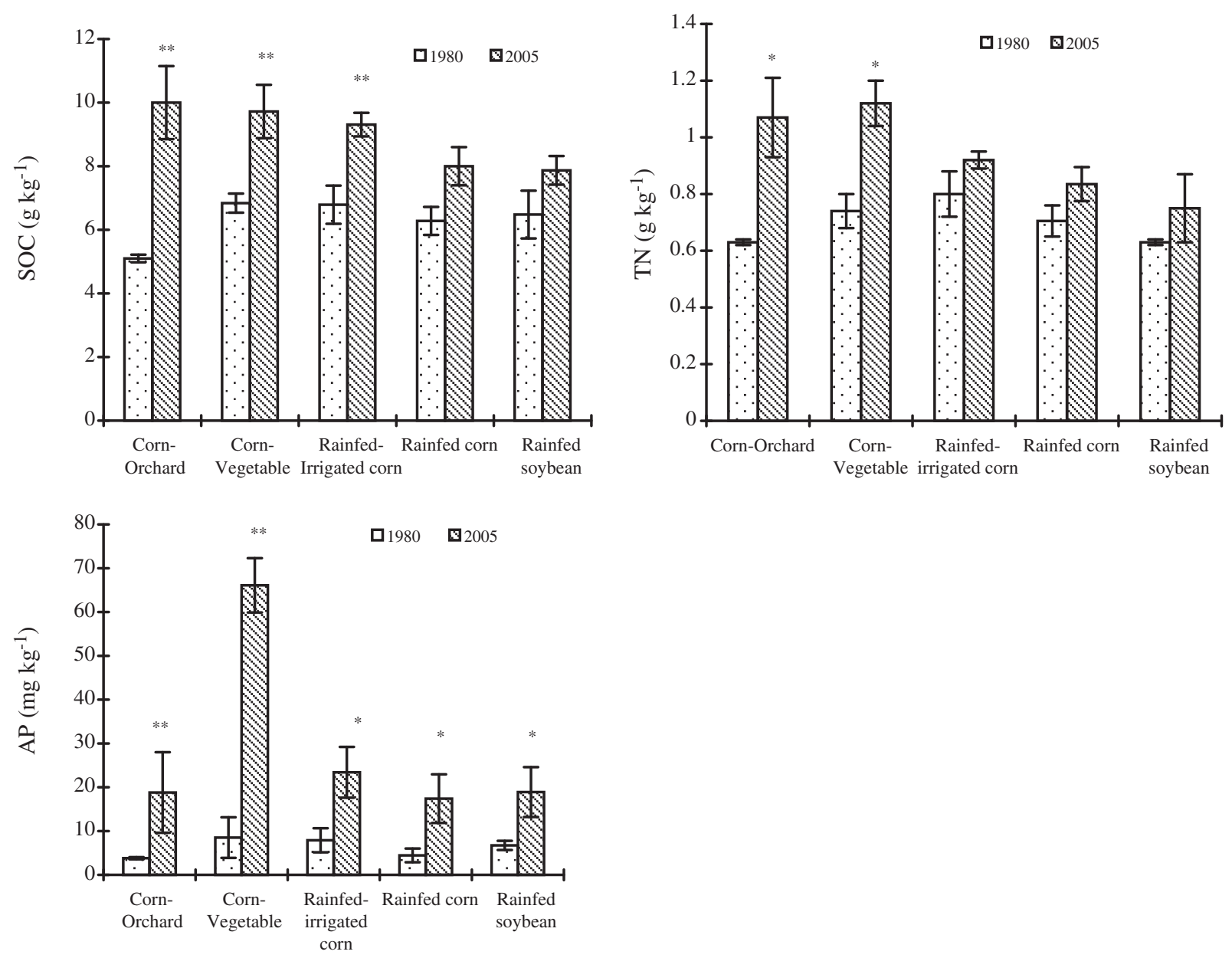

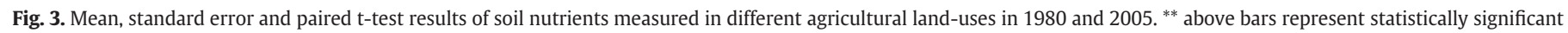
differences at $p<0.01$ from 1980 to 2005 . * above bars represents statistically significant differences at $p<0.05$ from 1980 to 2005 .

concentrations and $D_{b}$ values (Soil bulk density, Formula 1). $D_{b}$ values were very similar for the different agro-ecosystems (Table 1), which suggested that the patterns of soil nutrient density were mostly dependent on soil nutrient concentrations for all the land use types. Because there was practically no available P measured beneath $40 \mathrm{~cm}$, available $P$ densities in the $0-40 \mathrm{~cm}$ soil profiles were compared.

For the $100 \mathrm{~cm}$ soil profiles, SOC and total P densities were rated as: orchard (highest) $>$ vegetable $>$ irrigated corn $>$ rain fed soybean $>$ rain fed corn (lowest), and ranged from $9.22 \mathrm{~kg} \mathrm{~m}^{-2}$ to $5.54 \mathrm{~kg} \mathrm{~m}^{-2}$ for SOC and from $0.97 \mathrm{~kg} \mathrm{~m}^{-2}$ to $0.66 \mathrm{~kg} \mathrm{~m}^{-2}$ for total $\mathrm{P}$, respectively (Fig. 4). Total $\mathrm{N}$ densities in the $100 \mathrm{~cm}$ profile were ranked as: vegetable $>$ irrigated corn $>$ orchard $>$ rain fed soybean $>$ rain fed corn, and ranged from $0.92 \mathrm{~kg} \mathrm{~m}^{-2}$ to $0.57 \mathrm{~kg} \mathrm{~m}^{-2}$ (Fig. 4). Available P densities in the $40 \mathrm{~cm}$ profile were ranked as: vegetable (highest) $>$ irrigated corn $>$ rain fed corn $>$ rain fed soybean $>$ orchard (lowest), and ranged from $22.93 \mathrm{~g} \mathrm{~m}^{-2}$ to $4.36 \mathrm{~g} \mathrm{~m}^{-2}$ (Fig. 4). Available P densities in the vegetable soils $\left(22.93 \mathrm{~g} \mathrm{~m}^{-2}\right)$ were significantly higher than in the other studied soils (from $6.63 \mathrm{~g} \mathrm{~m}^{-2}$ to $4.36 \mathrm{~g} \mathrm{~m}^{-2}$ ).

\subsection{Effects of agricultural land-use on the other soil properties}

After intensive management for a period of between 8 and 20 years, the soil $D_{b}$, clay and AGG of the orchard and vegetable soils were not significantly different from those in the traditional cropping systems (Table 1 ). The soil $D_{b}$ varied from 1.36 to $1.42 \mathrm{~g} \mathrm{~cm}^{-3}$, and was slightly lower in the orchard soils than in soils from the other land uses. Clay and AGG accounted for about $5.0-6.0 \%$ and $21-24 \%$, respectively, with no significant difference between the studied soils. MBC under the various land uses ranged from 312 to $454 \mathrm{mg} \mathrm{C} \mathrm{kg}^{-1}$. Soil $\mathrm{pH}$ and EC ranged from 7.8 to 8.0 and 1.3 to $2.6 \mathrm{dS} \mathrm{m} \mathrm{m}^{-1}$, respectively. There was

Table 1

Mean, standard error (in parentheses) and ANOVA results of soil properties measured in different agricultural land uses in 2005 a $^{\mathrm{a}}$

\begin{tabular}{|c|c|c|c|c|c|}
\hline Land use & $\begin{array}{l}\text { Orchard } \\
(n=4)\end{array}$ & $\begin{array}{l}\text { Vegetable } \\
(n=6)\end{array}$ & $\begin{array}{l}\text { Irrigated corn } \\
(\mathrm{n}=12)\end{array}$ & $\begin{array}{l}\text { Rainfed corn } \\
(n=16)\end{array}$ & $\begin{array}{l}\text { Rainfed soybean } \\
(\mathrm{n}=3)\end{array}$ \\
\hline $\mathrm{D}_{\mathrm{b}}\left(\mathrm{g} \mathrm{cm}^{-3}\right)$ & $1.36(0.29) \mathrm{a}$ & $1.40(0.04) \mathrm{a}$ & $1.38(0.04) \mathrm{a}$ & $1.41(0.04) \mathrm{a}$ & $1.42(0.06) \mathrm{a}$ \\
\hline Clay (\%) & $5.0(1.0) \mathrm{a}$ & $5.6(0.4) \mathrm{a}$ & $6.0(0.3) \mathrm{a}$ & $5.3(0.5) \mathrm{a}$ & $6.0(0.5) \mathrm{a}$ \\
\hline AGG (\%) & $21(4) a$ & $21(3) \mathrm{a}$ & $24(3) \mathrm{a}$ & $23(2) a$ & $23(5) \mathrm{a}$ \\
\hline $\mathrm{pH}$ & $7.9(0.1) \mathrm{ab}$ & $7.8(0.1) \mathrm{b}$ & $8.0(0.1) a$ & $7.9(0.1) a b$ & $7.8(0.1) a b$ \\
\hline $\mathrm{EC}\left(\mathrm{dS} \mathrm{m}^{-1}\right)$ & $1.7(0.3) \mathrm{b}$ & $2.6(0.5) a$ & $1.5(0.1) \mathrm{b}$ & $1.4(0.1) b$ & $1.3(0.1) b$ \\
\hline $\mathrm{MBC}\left(\mathrm{mg} \mathrm{kg}^{-1}\right)$ & $344(51) a$ & $338(30) \mathrm{a}$ & $454(274) \mathrm{a}$ & $389(25)$ a & $312(7) \mathrm{a}$ \\
\hline
\end{tabular}

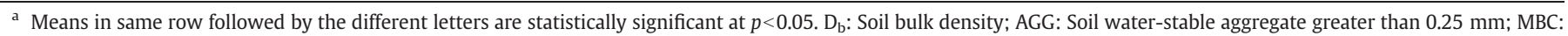
microbial biomass carbon; and EC: electrical conductivity. 

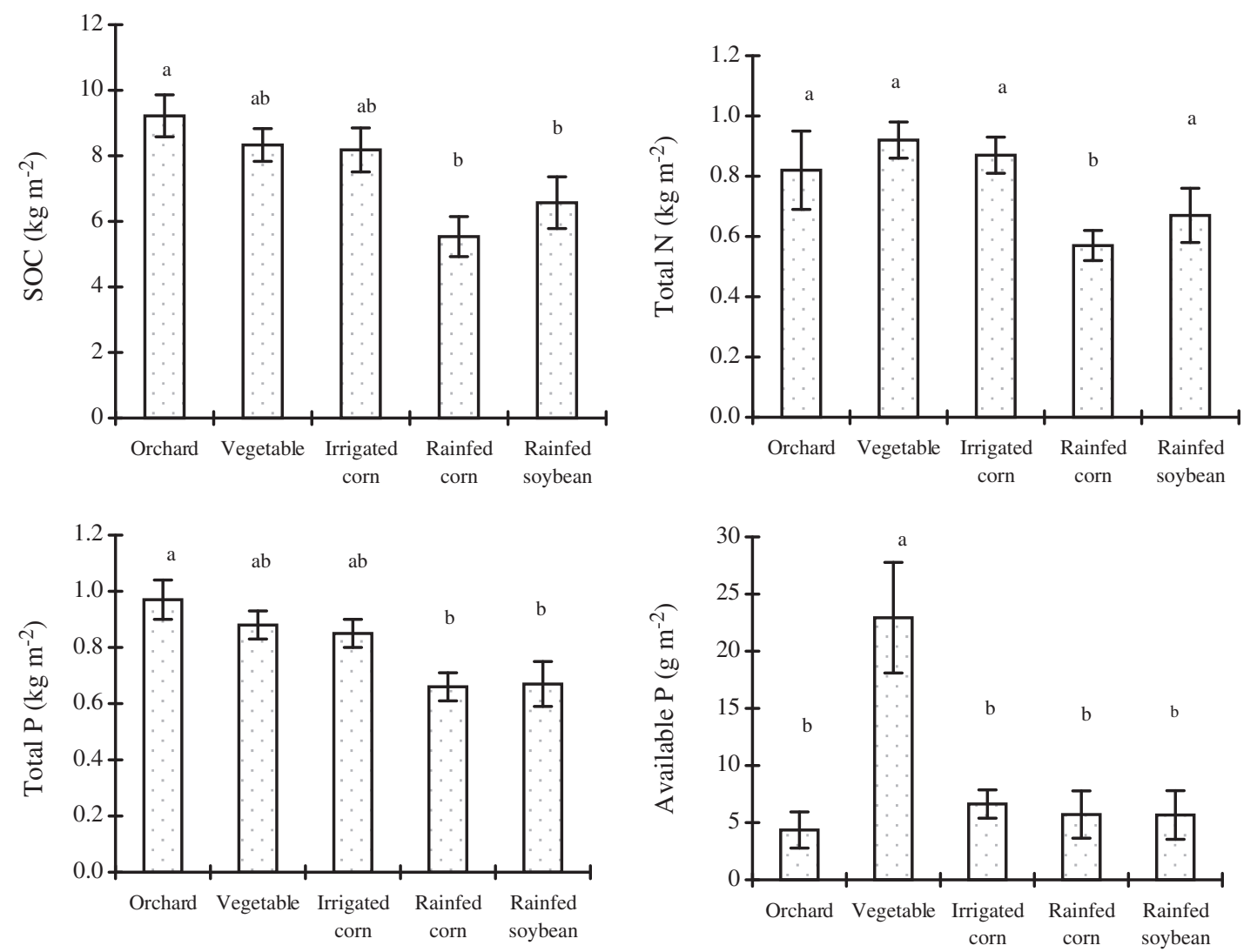

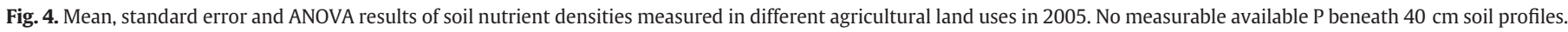
Different letters above bars represent statistically significant differences at $p<0.05$.

no significant difference in $\mathrm{MBC}$ and $\mathrm{pH}$ between different agricultural land-uses. Soil EC was significantly higher in soils from the vegetable fields than in soils from the other land use types.

\subsection{Relationships between soil nutrients and fertilization practices}

As expected, manure OM contributed significantly to the SOC, total $\mathrm{N}$, total $\mathrm{P}$ and available $\mathrm{P}$ contents, while mineral $\mathrm{P}$ fertilizer contributed significantly to the total $\mathrm{P}$ and available $\mathrm{P}$ (Table 2). However, the mineral $\mathrm{N}$ fertilizer not only contributed significantly to the total $\mathrm{N}$, but also contributed significantly to the total $\mathrm{P}$ and available P. Neither mineral $\mathrm{N}$ fertilizer nor mineral $\mathrm{P}$ fertilizer contributed significantly to the SOC content.

\section{Discussion}

\subsection{Change in soil nutrient contents in the past 25 years}

In general, intensive farming systems are known to cause a decline in SOC, resulting from changes to soil structure caused by tillage, removal of biomass, and increased mineralization and decomposition of exposed soils (Collard and Zammit, 2006; Goidts and Wesemael, 2007; Xu et al.,
2006; Zhang et al., 2007). However, intensive agricultural practices, such as integrated nutrient management based on liberal use of biosolids and compost, crop rotations that return large quantities of biomass, irrigation in a drought prone soil, could enhance the SOC stock (Lal, 2002, 2004a, 2004b). Higher fertilizer input and crop intensity and very low initial SOC content have been shown to contribute to greater OM input than oxidation release (Xu et al., 2006).

In our study, SOC, total $\mathrm{N}$ and available P contents in 1980 were low, corresponding to the low fertilization rates at the time and the long history of traditional cultivation, during which time most of the crop residue (including residual roots) was removed and used as fuel for cooking and heating (Zhang et al., 2004). The higher SOC, total $\mathrm{N}$ and available $P$ contents in 2005 resulted mainly from increased fertilizer and manure applications, as well as greater crop residue return. Returning crop residue, such as leaves and roots, to soils may have played an important role in the increases in SOC from 1980 to the 2000s (Fu et al., 2001; Kong et al., 2006; Post and Kwon, 2000; Xu et al., 2006). Increases in soil SOC, total N and available P were also reported in the other areas of China following land reform. For example, in the North Plain of China, the SOC, total and available N, and available P increased in farmland and paddy rice fields from the 1980s to the 2000s (Fu et al., 2001; Kong et al., 2006, 2009; Xu et al., 2006; Zhang et al., 2004). In the Jiangsu province,

Table 2

Correlations of soil nutrients in the top $20 \mathrm{~cm}$ of the soil profile and soil fertilization practices in 2005 .

\begin{tabular}{|c|c|c|c|c|c|c|c|c|}
\hline \multirow{2}{*}{$\begin{array}{l}\text { Soil nutrients } \\
\text { Fertilization practices (ton } \mathrm{ha}^{-1} \mathrm{yr}^{-1} \text { ) }\end{array}$} & \multicolumn{2}{|c|}{$\mathrm{SOC}\left(\mathrm{g} \mathrm{kg}^{-1}\right)$} & \multicolumn{2}{|c|}{ Total N $\left(\mathrm{g} \mathrm{kg}^{-1}\right)$} & \multicolumn{2}{|c|}{ Total P $\left(\mathrm{g} \mathrm{kg}^{-1}\right)$} & \multicolumn{2}{|c|}{ Available P $\left(\mathrm{mg} \mathrm{kg}^{-1}\right)$} \\
\hline & Coefficient & $p$ & Coefficient & $p$ & Coefficient & $p$ & Coefficient & $p$ \\
\hline Manure organic matter $(\mathrm{n}=22)$ & 0.817 & 0.047 & 0.878 & 0.021 & 0.906 & 0.013 & 0.876 & 0.022 \\
\hline Mineral nitrogen fertilization $(n=41)$ & 0.328 & 0.063 & 0.489 & 0.004 & 0.721 & 0.000 & 0.755 & 0.000 \\
\hline Mineral phosphorus fertilization $(n=41)$ & 0.100 & 0.581 & 0.238 & 0.183 & 0.800 & 0.000 & 0.819 & 0.000 \\
\hline
\end{tabular}


SOC, total N, and available P increased over the last two decades in the rice-wheat cropping system in paddy soils (Liu et al., 2009; Pan et al., 2005).

We may therefore conclude that inputs to the agro-ecosystems significantly exceeded the outputs from the soil, especially in the intensive agro-ecosystems over the last 25 years due to excess $\mathrm{N}$ and $\mathrm{P}$ fertilization, increases in crop residue return and irrigation.

\subsection{Effects of land-use and management change on soil nutrients}

When land previously used for corn or soybean production was converted to orchard or vegetable agro-ecosystems, fertilizer and manure applications and irrigation increased dramatically. Our survey results and other research results (Kong et al., 2006) showed that the low profit earning rain fed soybean lands had had a very similar nitrogen fertilization regime over the last 25 years. Since land reform, farmers have implemented more intensive management practices across the large area of rain fed corn to improve the income they earn from their land. Also, since the implementation of the household responsibility system in the late 1970s, farmers have adopted more intensive fertilization and irrigation practices in the more profitable orchard and vegetable agro-ecosystems, which have increased the soil nutrient input and soil moisture (Chen et al., 2006).

The orchard vegetation is perennial, while the other agricultural land-uses are annual. It has been reported that when intensively managed agricultural lands are converted and replanted with perennial vegetation, SOC will accumulate (Degryze et al., 2004; Gong et al., 2006; Post and Kwon, 2000). For SOC improvement it may be important to place OM deeper in the soil, either directly or indirectly by increasing below-ground inputs (Post and Kwon, 2000). The $D_{b}$ in the orchard decreased over the study time, although not significantly when compared with the other land uses, showing a trend of improved soil structure under orchard cultivation. SOC densities were higher in the $100-\mathrm{cm}$ soil profiles under orchard cultivation, which may be attributed to deeper root distributions (Zhang et al., 2006). Orchard planting can also improve the soil resistance to water and wind erosion, as there is no bare field period through the year. In addition, with the lowest available P contents and densities in the soil and higher profit, the orchard may be suggested as a better agro-ecosystem to sustain soil carbon and water quality in this water-source catchment.

The total $\mathrm{N}$ and total $\mathrm{P}$ concentrations and densities were higher in the vegetable soils, corresponding to the higher mineral fertilizer and manure inputs and higher irrigation frequency than in the other traditional agro-ecosystems. The available P concentrations and densities were significantly higher in the vegetable soils than in soils from all the other agro-ecosystems, and also higher than those found in other Chinese catchments (Liu et al., 2009; Wang et al., 2003). The high available P concentration is no doubt attributable to excessive applications of mineral P. Phosphorus applications as manure to agricultural soils in arable cropping systems often exceed P uptake by crops (Hooda et al., 2001). Long-term flooding, in this case by irrigation, may also increase soil P availability (Liu et al., 2009). Consequently, high values of available $P$, intensive fertilization and irrigation on the vegetable soils are the main issues for off-site transport of $P$ and surface water eutrophication in this water-supply catchment. This is in agreement with the results of the Revised Field Phosphorus Ranking Scheme (Li et al., 2007). Furthermore, the significantly higher EC in the vegetable farms suggests that the intensive fertilization and irrigation practices may lead to soil salinization.

There were no significant differences between SOC, total $\mathrm{N}$ and total $P$ concentrations and densities in soils from orchard, vegetable and irrigated corn lands. SOC, total $\mathrm{N}$ and total $\mathrm{P}$ densities were higher in the irrigated corn lands with more fertilizer and irrigation than in the rain fed corn lands, which had less fertilizer and no irrigation. Balanced mineral fertilization along with an adequate amount of farmyard manure is suitable for cultivated cropping systems to improve SOC stock and nutrient contents (Majumder et al., 2008; Liu et al., 2010). But in the rain fed corn and soybean systems, the low outputs and equally low inputs have led to an exaggeration of the differences between the soil properties of the irrigated corn and rain fed corn lands.

Increasing the inputs of manure, suitable fertilizer and irrigation frequency across the large area of rain fed corn land in the study area has been very important for improving soil quality and increasing the net income. With increasing agricultural intensification, a balanced nutrient budget is critical for sustainable productivity (Chen et al., 2006). In the study catchment, high profit, rather than environmental protection, is the first priority of farmers, and is pursued through diversification of land use and high inputs of fertilizers, manure and irrigation. Local farmers give little consideration to the protection of the water source and most farmers judge their soils and soil fertility empirically. However, if agricultural development is to continue in this water source catchment, dissemination of knowledge about sustainable management of soil and water is essential.

\section{Conclusions}

Intensive land use types and management practices, such as orchard, vegetable and rain fed corn lands with more fertilizer inputs, could improve soil nutrients, but the risk of non-point source pollution to water should be considered, especially for vegetable lands. Available P contents and densities were much higher in the vegetable soils than in the other agro-ecosystems. SOC, total N and total P contents had increased significantly in vegetable and orchard soils by 2005 when compared with the soils in 1980. SOC, total $\mathrm{N}$ and total $\mathrm{P}$ contents and densities were higher in the orchard and vegetable soils than in the rain fed corn and soybean soils. Our results suggest that orchard systems can help improve soil nutrients and at the same time, have a low risk to water quality. However, the risk of available P loss to waterways from vegetable farms and salinization in vegetable soils is high. Due to the significant increase in the available $P$ content over the last 25 years, mineral $P$ applications should be restricted in this water-supply catchment, especially in the vegetable lands.

\section{Acknowledgments}

We would like to thank Dr. Deborah Jayne Ballantine from the National Institute of Water and Atmospheric Research Ltd (NIWA), New Zealand for her constructive comments and help on English revision. We thank two anonymous reviewers for their critical and constructive comments on the manuscript. The authors sincerely acknowledge the financial support provided by the Knowledge Innovation Program of the CAS (KZCX2-EW-310) and National Science Foundation for Distinguished Young Scholars of China (No. 40925003).

\section{References}

Bennett, E.M., Carpenter, S.R., Clayton, M.K., 2005. Soil phosphorus variability: scaledependence in an urbanizing agricultural landscape. Landscape Ecology 20, 389-400.

Blake, G.R., Hartge, K.H., 1986. Bulk density, In: Klute, A. (Ed.), Methods of Soil Analysis, Part I. Physical and Mineralogical Methods, 2nd ed. Agronomy Monograph No. 9, pp. 363-375.

Chen, L.D., Wang J., Fu, B.J., Qiu, Y., 2001. Land-use change in a small catchment of northern Loess Plateau, China. Agriculture, Ecosystems and Environment 86, 163-172.

Chen, J., Yu, Z.R., Ouyang, J.L., Mensvoort, M.E.F.v, 2006. Factors affecting soil quality changes in the North China Plain: a case study of Quzhou County. Agricultural Systems 91, 171-188.

Collard, S.J., Zammit, C., 2006. Effects of land-use intensification on soil carbon and ecosystem services in Brigalow (Acacia harpophylla) landscapes of southeast Queensland, Australia. Agriculture, Ecosystems and Environment 117, 185-194.

Degryze, S., Six, J., Paustian, K., Morris, S.J., Paul, E.A., Merck, R., 2004. Soil organic carbon pool changes following land-use conversions. Global Change Biology 10, 1120-1132.

Elliott, E.T., 1986. Aggregate structure and carbon, nitrogen, and phosphorus in native and cultivated soils. Soil Science Society of America Journal 50, 627-633.

Franzluebbers, A.J., Stuedemann, J.A., 2010. Surface soil changes during twelve years of pasture management in the southern piedmont USA. Soil Science Society of America Journal 74, 2131-2141. 
Fu, B.J., Guo, X.D., Chen, L.D., Ma, K.M., Li, J.R., 2001. Soil nutrient changes due to land use changes in Northern China a case study in Zunhua County Hebei Province. Soil Use and Management 17, 294-296.

Goidts, E., Wesemael, B.v, 2007. Regional assessment of soil organic carbon changes under agriculture in Southern Belgium (1955-2005). Geoderma 141, 341-354.

Gong, J., Chen, L.D., Fu, B.J., Huang, Y.L., Huang, Z.L., Peng, H.J., 2006. Effect of land use on soil nutrients in the loess hilly area of the Loess Plateau, China. Land Degradation and Development 17, 453-465.

Hooda, P.S., Truesdale, V.W., Edwards, A.C., Withersc, P.J.A., Aitkend, M.N., Miller, A., Rendell, A.R., 2001. Manuring and fertilization effects on phosphorus accumulation in soils and potential environmental implications. Advances in Environmental Research 5, 13-21.

Jenkinson, D.S., Powlson, D.S., 1976. The effects of biocidal treatments on metabolism in soil-V: a method for measuring soil biomass. Soil Biology and Biochemistry 8 , 209-213.

Kong, X.B., Zhang, F.R., Wei, Q., Xu, Y., Hui, J.G., 2006. Influence of land use change on soil nutrients in an intensive agricultural region of North China. Soil and Tillage Research 88, 85-94.

Kong, X.B., Dao, T.H., Qin, J., Qin, H.Y., Li, C.Z., Zhang, F.R., 2009. Effects of soil texture and land use interactions on organic carbon in soils in North China cities' urban fringe. Geoderma 154, 86-92.

Lal, R., 2002. Soil carbon sequestration in China through agricultural intensification, and restoration of degraded and desertified ecosystems. Land Degradation and Development $13,469-478$

Lal, R., 2004a. Soil carbon sequestration impacts on global climate change and food security. Science 304, 1623-1627.

Lal, R., 2004b. Soil carbon sequestration to mitigate climate change. Geoderma 123, 1-22.

Lettens, S., Orshoven, J.V., Wesemael, B.V., Vos, B.D., Muys, B., 2005. Stocks and fluxes of soil organic carbon for landscape units in Belgium derived from heterogeneous data sets for 1990 and 2000. Geoderma 127, 11-23.

Li, Q., Chen, L.D., Qi, X., Zhang, X.Y., Ma, Y., Fu, B.J., 2007. Assessing field vulnerability to phosphorus loss in Beijing agricultural area using revised field phosphorus ranking scheme. Journal of Environmental Sciences 19, 977-985.

Liu, X.M., Zhang, W.W., Zhang, M.H., Ficklin, D.L., Wang, F., 2009. Spatio-temporal variations of soil nutrients influenced by an altered land tenure system in China. Geoderma 152, 23-34.

Liu, E.K., Yan, C.R., Mei, X.R., He, W.Q., Bing, S.H., Ding, L.P., Liu, Q., Liu, S., Fan, T.L., 2010. Long-term effect of chemical fertilizer, straw, and manure on soil chemical and biological properties in northwest China. Geoderma 158, 173-180.

Majumder, B., Mandal, B., Bandyopadhyay, P.K., Gangopadhyay, A., Mani, P.K., Kundu, A.L., Mazumdar, D., 2008. Organic amendments influence soil organic carbon pools and rice-wheat productivity. Soil Science Society of America Journal 72, 775-785.

McGill, W.B., Figueiredo, C.T., 1993. Total nitrogen. In: Carter, M.R. (Ed.), Soil Sampling and Methods of Analysis. Lewis Publishers, Boca Raton, FL, pp. 201-211.
Olsen, S.R., Sommers, L.E., 1982. Phosphorus. In: Page, A.L., Miller, R.H., Kenny, D.R (Eds.), Methods of Soil Analysis. Part 2. American Society of Agronomy, Madison, pp. 403-430.

Pan, G., Li, L., Zhang, Q., Wang, X., Sun, X., Xu, X., Jiang, D., 2005. Organic carbon stock in topsoil of Jiangsu Province, China, and the recent trend of carbon sequestration. Journal of Environmental Sciences 17, 1-7.

Physical geography laboratory manual. http://www.ex.ac.uk/\%7EARAmes/labmanua htm.

Post, W.M., Kwon, K.C., 2000. Soil carbon sequestration and land-use change processes and potential. Global Change Biology 6, 317-327.

Qin, J., Kong, X.B., Zhang, F.R., Miao, Y.X., Liu, L.W., 2007. Change of soil organic matter as affected by household land use based on 3S technology in urban fringes of north China. New Zealand Journal of Agricultural Research 50, 1093-1102.

Rawls, W.J., 1983. Estimating soil bulk density from particle size analysis and organic matter contents. Soil Science 135, 123-125.

Soil Survey Staff, 2010. Keys to Soil Taxonomy, 11th ed. USDA Natural Resources Conservation Service, Washington, DC.

Tiessen, H., Moir, J.O., 1993. Total and organic carbon. In: Carter, M.R. (Ed.), Soil Sampling and Methods of Analysis. Lewis Publishers, Boca Raton, FL, pp. 187-199.

Wang, J., Fu, B.J., Qiu, Y., Chen, L.D., 2003. Analysis on soil nutrient characteristics for sustainable land use in Danangou catchment of the Loess Plateau, China. Catena 54, 17-19.

Wang, T.Y., Lu, Y.L., Shi, Y.J., Giesy, J.P., Luo, W., 2007. Organochlorine pesticides in soils around Guanting Reservoir, China. Environmental Geochemistry and Health 29 491-501.

Wells, A.T., Chan, K.Y., Cornish, P.S., 2000. Comparison of conventional and alternative vegetable farming systems on the properties of a yellow earth in New South Wales. Agriculture, Ecosystems and Environment 80, 47-60.

Xu, Y., Zhang, F.R., Hao, X.Y., Wang, J.K., Wang, R., Kong, X.B., 2006. Influence of management practices on soil organic matter changes in the Northern China plain and Northeastern China. Soil and Tillage Research 86, 230-236.

Yanqing County Official Statistical Agency, 1982, 2004. Economy Statistical Almanac of Yanqing County, Beijing Municipality . (In Chinese).

Yanqing Soil Survey Staff, 1983. Yanqing Soil Reference Book. Yanqing, Beiing. (In Chinese).

Zhang, F.R., Hao, X.Y., Wang, R., Xü, Y., Kong, X.B., 2004. Changes in soil properties in southern Beijing Municipality following land reform. Soil and Tillage Research $75,143-150$.

Zhang, X.Y., Chen, L.D., Fu, B.J., Li, Q., Qi, X., Ma, Y., 2006. Soil organic carbon changes as influenced by agricultural land use and management: a case study in Yanhuai Basin, Beijing, China. Acta Ecologica Sinica 26, 3198-3203.

Zhang, H., Zhang, G.L., Zhao, Y.G., Zhao, W.J., Qi, Z.P., 2007. Chemical degradation of a Ferralsol (Oxisol) under intensive rubber (Hevea brasiliensis) farming in tropical China. Soil and Tillage Research 93, 109-116. 